\title{
ANALISIS PENGUNGKAPAN SUKARELA PADA BANK UMUM SYARIAH DI INDONESIA
}

\author{
Muhammad Haidir Ali dan Ahmad Tarmizi Lbs \\ Program Studi Akuntansi Syariah \\ Sekolah Tinggi Ekonomi Islam SEBI \\ Email:alie6607@gmail.com
}

\begin{abstract}
This study is a descriptive study to assess voluntary disclosure in annual reports Islamic Banks (iB) with that should be disclosed. Annual reports used in this study is an annual report $\mathrm{iB}$ in Indonesia in 2011, 2012, and 2013. This research is relatively new because no one has done research on voluntary disclosure in Islamic Banks (iB). Therefore, in order to study to obtain maximum results, the coding instructions for voluntary disclosure must be in accordance with the study conducted by Rr. Puruwita Wardani (2012) entitled "Factors Affecting Voluntary Disclosure area. Analysis tools are used is the content analysis by collecting words that expressed the count. The results showed that during the three-year study period, 2011, 2012, and 2013 there was an increase in the provision of good disclosure of the number of items disclosed or revealed $\mathrm{iB}$ number. But overall tenth $\mathrm{iB}$ already provide adequate voluntary disclosure to reveal the items contained in the variable voluntary disclosure even though the iB newly established in 2010.
\end{abstract}

Keywords: disclosure, annual reports, voluntary disclosure, content analysis

\section{PENDAHULUAN}

Laporan keuangan suatu perusahaan merupakan sebuah informasi yang menjelaskan kondisi suatu perusahaan. Sebuah laporan keuangan disusun pada dasarnya untuk memenuhi kepentingan para pengguna dari laporan keuangan tersebut. Laporan keuangan ini digunakan oleh pengguna untuk melakukan analisis mengenai keberhasilan manajemen dalam mengelola perusahaan.

Dalam kontekstual angka-angka numerik, hal tersebut memang terlampir dalam laporan keuangan utama yang empat, yaitu laporan posisi keuangan, laporan laba rugi, laporan perubahan ekuitas dan laporan arus kas. Namun dalam laporan keuangan utama masih ada batasan serta belum mewakili penjelasan mengenai rincian dari angka-angka numerik yang disajikan dalam laporan keuangan tersebut. Oleh karena itulah sebuah satu set komponen dari laporan keuangan tidak pernah terlepas dari catatan atas laporan keuangan yang berfungsi untuk menjelaskan secara terperinci dari peristiwa yang dipaparkan dalam angka numerik pada laporan keuangan utama itu sendiri.

Catatan atas laporan keuangan merupakan tambahan informasi mengenai rincian jumlah yang tertera dalam laporan keuangan utama. Rincian tersebut merupakan ringkasan dari angka-angka yang tersajikan 
dalam laporan keuangan utama. Begitu pula penjelasan mengenai transaksi yang terjadi selama periode tersebut yang dicatat dalam laporan keuangan utama dijelaskan dalam catatan atas laporan keuangan, baik itu penjelasan mengenai kebijakan akuntansi, metode yang digunakan dalam pencatatan akuntansi dan lain sebagainya. Pembuatan catatan atas laporan keuangan pada dasarnya harus mengacu kepada Pernyataan Standar Akuntansi Keuangan (PSAK). Di dalam PSAK telah diatur hal-hal yang harus diungkapkan sebagai penjelasan dari komponen laporan keuangan utama yang merupakan rincian yang akan ditampilkan dalam laporan keuangan. Hal-hal yang perlu diungkapkan dalam catatan atas laporan keuangan tersebut pada dasarnya terdiri dari dua jenis, yaitu pengungkapan yang bersifat wajib (mandatory disclosure) dan pengungkapan yang bersifat sukarela (voluntary disclosure).

Bank Indonesia melalui Surat Edaran BI No. 7/56/DPbs tentang laporan tahunan, telah menjelaskan poin-poin yang perlu untuk diungkapkan, begitu pula pada laporan keuangan publikasi triwulanan dan bulanan serta laporan tertentu dari bank yang harus disampaikan kepada Bank Indonesia. Pengungkapan wajib (mandatory disclosure) merupakan pengungkapan minimum yang diisyaratkan oleh peraturan yang berlaku. Sebagaimana telah diatur dalam PSAK (Pernyataan Standar Akuntansi Keuangan).

Sedangkan pengungkapan yang bersifat sukarela pada dasarnya diberikan keleluasaan bagi perusahaan dalam mengungkapkannya. Hal ini tidak bersifat wajib seperti dalam pengungkapan yang telah diatur dalam PSAK. Namun jika dilihat dari kerangka konseptual pada prinsip dasar akuntansi, perusahaan dituntut untuk melakukan pengungkapan penuh (full disclosure), perusahaan diharapkan mampu memberikan pengungkapan yang lebih luas mengenai kondisi yang terjadi dalam perusahaan. Luas dalam artian disini, dimaksudkan akan menjelaskan pengungkapan yang tidak diungkapkan dalam pengungkapan wajib dalam artian itulah pengungkapan sukarela. Hal ini terkait dengan penjelasan mengenai transaksi, keadaan manajemen, risiko-risiko yang terjadi, serta pertanggungjawaban manajemen lainnya. Namun, penjelasan disini diberikan kebebasan kepada perusahaan dalam melakukan pengungkapkan, dengan catatan masih dalam tahap wajar dan perlu untuk diungkapkan. Karena pada prinsipnya hal tersebut perlu disajikan kepada publik sebagai bentuk pertanggungjawaban agar pihakpihak yang berkepentingan terhadap laporan keuangan mampu mengambil keputusan dan informasi-informasi yang lebih akurat dan bermanfaat.

Pengungkapan pada dasarnya tidak melihat kriteria dari setiap perusahaan. Baik besar kecilnya ukuran perusahaan, ruang gerak lini bisnis baik itu, manufaktur, dagang, atau jasa, prinsip yang dijalankan baik itu konvensional atau syariah tidak ada ketentuan yang mengharuskan terkait luas pengungkapan sebuah laporan tahunan perusahaan. Semua jenis perusahaan dituntut untuk melakukan pengungkapan seluas-luasnya. Namun tetap dibatasi sesuai dengan manfaat daripada pengungkapan yang harus disajikan dibandingkan dengan biaya yang harus dikeluarkan. Seperti yang tercantum dalam PSAK bahwa perusahaan selagi memberikan manfaat yang 
efektif dibandingkan dengan biaya yang dikeluarkan boleh mengungkapan seluas-luasnya sekalipun perlu untuk diungkapkan (Ikatan Akuntan Indonesia (IAI), 2009)

Akan tetapi berdasarkan penelitian yang dilakukan oleh Daniel (2013) tentang pengaruh ukuran perusahaan, leverage dan likuiditas terhadap luas pengungkapan laporan keuangan yang dilakukan di perusahaan manufaktur menunjukkan bahwa ukuran perusahaan dan likuiditas berpengaruh positif dan signifikan terhadap luas pengungkapan laporan keuangan pada perusahaan manufaktur yang terdaftar di Bursa Efek Indonesia.

Sedangkan untuk yang bersifat sukarela penelitian dilakukan oleh Hadi (2001) mengenai analisis faktor-faktor yang mempengaruhi luas pengungkapan sukarela dalam laporan tahunan perusahaan manufaktur yang sudah gopublic di Bursa Efek. Adapun faktor-faktor yang digunakan dalam melakukan penelitian ini yaitu size perusahaan, rasio likuiditas, basis perusahaan, solvabilitas, proporsi kepemilikan publik. Hasil penelitian menunjukkan bahwa semakin besar size perusahaan akan memberikan pengungkapan secara sukarela dalam laporan tahunan secara luas. Luas pengungkapan sukarela dalam laporan tahunan dipengaruhi oleh basis perusahaan. Dengan demikian penelitian ini menguatkan penelitian Daniel (2013)

Penelitian dengan tema yang serupa oleh Almilia (2008) tentang faktor-faktor yang mempengaruhi kelengkapan sukarela "Internet Financial and Sustainability Reporting”. Dengan variabel yang digunakan yaitu size perusahaan, rasio profitabilitas, leverage, kepemilikan pihak luar. Penelitian ini berusaha menguji faktor apa sajakah yang mempengaruhi pengungkapan melalui media website perusahaan ini. Dengan menggunakan sampel 104 perusahaan, penelitian ini memberikan bukti bahwa size perusahaan, profitabilitas perusahaan dan kepemilikan mayoritas merupakan variabel yang menentukan tingkat pengungkapan sukarela perusahaan yang ditunjukkan dengan peningkatan indeks IFSR.

Tristanti (2012) menguji kembali mengenai analisis pengaruh karakteristik perusahaan terhadap pengungkapan sukarela pada perusahaan manufaktur yang terdaftar di Bursa Efek periode 2006-2010. Variabel yang digunakan dalam penelitian adalah likuiditas, leverage, profitabilitas, ukuran perusahaan, status perusahaan, umur perusahaan, proporsi kepemilikan saham publik. Hasil penelitian menguatkan penelitian yang dilakukan oleh Hadi (2001) dan Almilia (2008) dengan menunjukkan bahwa secara parsial hanya variabel ukuran perusahaan, rasio profitabilitas, dan proporsi kepemilikan saham oleh publik, yang memiliki pengaruh positif terhadap kelengkapan pengungkapan sukarela dalam laporan tahunan perusahaan manufaktur.

Lalu Wardani (2012) melanjutkan penelitian yang dilakukan oleh Hadi (2001) mengenai faktor-faktor yang mempengaruhi luas pengungkapan sukarela. Dengan menganalisis ukuran perusahaan, leverage, porsi kepemilikan saham, likuiditas perusahaan, profitabilitas, serta umur perusahaan. Sampel yang digunakan dalam penelitian ini adalah 79 
perusahaan sektor riil yang terdaftar di BEI periode 2009. Hasil penelitian menguatkan penelitian yang dilakukan oleh Almilia (2008) dan Tristanti (2012) bahwa ukuran perusahaan dan profitabilitas berpengaruh secara positif terhadap luas pengungkapan sukarela.

Bank syariah merupakan sebuah lembaga bisnis yang berdasarkan prinsip syariah juga dituntut untuk menyajikan laporan pertanggungjawaban kepada pihak-pihak yang berkepentingan yang tergambar dalam satu set laporan keuangan. Maka dengan demikian, prinsip pengungkapan penuh sudah sepatutnya harus dipegang teguh oleh bank syariah itu sendiri. Bahkan bagi bank syariah prinsip pengungkapan ini tidak hanya cukup pada pengungkapan wajib saja.

Mengambil hukum taklifi sebagai salah satu dari hukum syara' dalam Islam berupa perintah dan larangan, dan takhyir (pilihan) menjelaskan bahwa ada lima hukum dalam Islam, yaitu wajib, mandhub (sunnah), makruh, haram, dan mubah yang dalam penelitian ini kita hanya akan mengambil hukum wajib dan sunnah. Wajib adalah suatu perintah yang harus dikerjakan, dimana orang yang meninggalkannya akan berdosa (Zahrah, Hukum Taklifi, 2012). Sedangkan untuk mandhub atau sunnah sebagaimana dijelaskan dalam kitab Abdul Wahab Khalaf adalah sebuah perintah yang diminta untuk dikerjakan kepada seorang mukallaf tanpa adanya paksaan. Atau juga suatu perintah yang apabila dikerjakan memperoleh pujian dan jika ditinggalkan tidak tercela menurut syara' (Zahrah, Hukum Taklifi, 2012). Jika dianalogikan kepada hal pengungkapan dalam akuntansi, seharusnya bank syariah sebagai bank yang menjalankan prinsip syariah tidak hanya memberikan pengungkapan yang bersifat wajib saja sebagaimana diatur dalam PSAK, namun juga perlu melakukan pengungkapan sukarela. Walaupun memang tidak wajib, tetapi sudah menjadi keharusan bagi lembaga bisnis yang menjalankan prinsip syariah untuk memberikan pengungkapan secara transparan kepada para pemegang kepentingan dan juga pengguna dari laporan keuangan sebuah perusahaan agar tidak hanya mendapatkan kemuliaan di hadapan Allah SWT, tetapi mendapat kepercayaan yang tinggi dari nasabah.

Penelitian mengenai luas pengungkapan sukarela belum pernah dilakukan pada bank syariah. Penelitian tersebut kebanyakan dilakukan pada perusahaan dagang dan perusahaan manufaktur yang terdaftar di Bursa Efek dan perusahaan real estate saja. Sedangkan penelitian pada bank umum syariah hanya berkutat pada penelitian mengenai pengungkapan laporan keuangan, pengungkapan Corporate Social Responsibility (tanggung jawab sosial) dan juga pengungkapan nilai-nilai Islam. Hal ini yang menjadi menarik bagi peneliti untuk melakukan penelitian mengenai pengungkapan sukarela pada bank umum syariah karena bank syariah sebagai lembaga bisnis yang menganut prinsip syariah tidak hanya fokus kepada hal-hal yang bersifat wajib saja akan tetapi perlu adanya pengungkapan sukarela pada bank umum syariah di Indonesia. 


\section{LANDASAN TEORI}

\subsection{PENGUNGKAPAN SUKARELA}

Pengungkapan secara sukarela (voluntary) adalah hal-hal yang diungkapkan bukan merupakan pengungkapan yang telah disajikan dalam laporan keuangan, dalam artian pengungkapan tersebut tidak diatur dalam standar akuntansi yang berlaku. Dan dalam hal ini merupakan pengungkapan laporan tahunan perusahaan.Daniel (2013) mengatakan pengungkapan sukarela adalah pengungkapan yang dilakukan perusahaan di luar apa yang diwajibkan oleh standar akuntansi atau peraturan badan pengawas. Sedangkan menurut (Meek, at al, 1995) yang dikemukakan oleh (Hardiningsih, Analisis Faktor-Faktor yang Mempengaruhi Voluntary Disclosure Laporan Tahunan Perusahaan, 2008) bahwa voluntary disclosure adalah pengungkapan informasi melebihi yang diwajibkan karena dipandang relevan dengan kebutuhan pemakai laporan keuangan.

Pengungkapan sukarela (voluntary disclosure) merupakan pilihan bebas manajemen perusahaan untuk memberikan informasi akuntansi dan informasi lainnya yang dipandang relevan untuk pembuatan keputusan oleh pemakai laporan tahunannya (Meek et. al., 1995) dalam (Tristanti, 2012). Pihak investor membuat keputusan investasinya berdasarkan pengungkapanpengungkapan dari suatu perusahaan. Informasi perusahaan yang bersifat wajib seringkali dirasa kurang mencukupi oleh investor, sehingga pengungkapan sukarela menjadi informasi penting bagi investor untuk membuat keputusan yang lebih baik.

Testiana (2012) berpendapat bahwa voluntary disclosure merupakan pengungkapan butir-butir yang dilakukan sukarela oleh perusahaan tanpa diharuskan oleh peraturan yang berlaku. Healy dan Palepu (1993) dalam (Testiana, Analisis Pengaruh Karakteristik Perusahaan Terhadap Kelengkapan Pengungkapan Sukarela Pada Perusahaan Manufaktur yang Terdaftar di Bursa Efek Indonesia, 2012) mengemukakan meskipun semua perusahaan publik diwajibkan memenuhi pengungkapan minimum, mereka berbeda secara substansial dalam hal jumlah tambahan informasi.

Menurut Wallace et. al. (1994) dalam (Tristanti, 2012) pengungkapan sukarela merupakan salah satu cara meningkatkan kredibilitas pelaporan keuangan perusahaan dan membantu investor dalam memahami strategi bisnis perusahaan. Perusahaan memenuhi kebutuhan tersebut sebagian melalui pemberian informasi secara sukarela.

Pertimbangan manajemen untuk mengungkapkan informasi secara sukarela dipengaruhi oleh faktor biaya dan manfaat. Manajemen akan mengungkapkan informasi secara sukarela apabila manfaat yang diperoleh dari pengungkapan informasi tersebut lebih besar dari biayanya. Karena informasi merupakan sinyal bagi para investor dalam memeberikan prospek perusahaan yang bersangkutan, maka tersedianya informasi yang benar-benar dapat dipercaya, lengkap, dan tepat waktu, akanmemungkinkan investor untuk melakukan pengambilan keputusan investasi secara rasional, sehingga yang diperoleh sesuai dengan harapan yang diinginkan investor. 
Menurut Suripto (1999) dalam (Hardiningsih, Analisis Faktor-Faktor yang Mempengaruhi Voluntary Disclosure Laporan Tahunan Perusahaan, 2008) menggolongkan biaya-biaya pengungkapan informasi perusahaan menjadi dua, yaitu:

1. Biaya Langsung

Biaya pengungkapan langsung adalah biaya-biaya yang dikeluarkan oleh perusahaan untuk mengembangkan dan menyajikan informasi, seperti biaya pengumpulan, biaya pemprosesan, biaya pengauditan, dan biaya penyebaran informasi.

\section{Biaya Tidak Langsung}

Biaya pengungkapan tidak langsung adalah biaya yang timbul akibat diungkapkannya maupun tidak diungkapkannya suatu informasi, seperti biaya litigasi (biaya ini timbul karena pengungkapan informasi yang tidak mencukupi atau pengungkapan informasi yang menyesatkan) dan biaya proprietary (biaya competitive disadvantage dan biaya politik)

Pengungkapan sukarela memiliki kelemahan sebagai berikut: Pertama, jika laporan tersebut memberikan berita baik kepada pengguna laporan keuangan, maka perusahaan cenderung akan mengungkapkan berita tersebut. Namun sebaliknya jika laporan tersebut memberikan berita buruk, maka perusahaan cenderung tidak akan menerbitkan laporan keuangan apalagi jika dampaknya bisa mempengaruhi perusahaan. Kedua, pengungkapan sukarela berarti pengungkapan yang dilakukan atas dasar inisiatif perusahaan tanpa adanya unsur paksaan dalam mengungkapkan laporan keuangan perusahaan.

\section{METODOLOGI PENELITIAN}

\subsection{METODE PENELITIAN, POPULASI DAN SAMPEL}

Penelitian ini menggunakan metode kualitatif dengan pendekatan deskriptif. Metode pendekatan kualitatif menggunakan pendekatan data-data kualitatif bukan angka yang dikumpulkan melalui pengamatan (observation), wawancara, telaah dokumen, rekaman, video, gambar, catatan lapangan dan sebagainya (Suryana, 2007). Sedangkan penelitian deskriptif adalah penelitian yang dilakukan untuk mengetahui variabel mandiri tanpa membuat perbandingan atau menghubungkan dengan variabel yang lain (Sugiyono, 2008). Tujuan dari penelitian kualitatif deskriptif adalah untuk mengetahui pengungkapan sukarela pada Bank Umum Syariah.

Populasi dalam penelitian ini merupakan seluruh Bank Umum Syariah di Indonesia yang tercatat di statistik perbankan syariah yang diterbitkan oleh BI (Bank Indonesia) yang per 1 Januari 2014 berpindah kekuasaan kepada OJK (Otoritas Jasa Keuangan) periode 2011-2013. Dan jumlah Bank Umum Syariah (BUS) yang tercatat sebanyak sebelas (11) BUS, yaitu Bank Muamalat Indonesia (BMI), Bank Central Asia Syariah (BCAS), Bank Jabar 
Banten Syariah (BJBS), Bank Mega Syariah Indonesia (BMSI), Bank Negara Indonesia Syariah (BNIS), Bank Rakyat Indonesia Syariah (BRIS), Bank Syariah Mandiri (BSM), Bank Syariah Bukopin (BSB), Bank Victoria Syariah (BVS), Panin Bank Syariah (PBS), dan Maybank Syariah (MS).

Sampel terpilih dengan purposive sampling dengan kriteria hanya Bank Umum Syariah yang menerbitkan Laporan Tahunan dan Laporan Keuangan periode 2011-2013 serta Laporan Keuangan yang berakhir 31 Desember, sehingga terdapat sepuluh Bank Umum Syariah karena Bank Jabar Banten Syariah (BJBS) hanya menerbitkan laporan keuangan periode 2011 tanpa menerbitkan laporan tahunannya.

\subsection{TEKNIK PENGUMPULAN DATA DANVARIABEL PENELITIAN}

Teknik pengumpulan data dalam penelitian ini menggunakan data sekunder. Adapun data sekunder yang digunakan yaitu laporan keuangan sepuluh Bank Umum Syariah periode 2011-2013 yang bisa diperoleh dari web masingmasing bank syariah itu sendiri, kemudian ada juga beberapa jurnal yang digunakan untuk membantu penulis dalam melakukan analisis pembahasan.

Variabel dalam penelitian ini adalah pengungkapan sukarela. Karena dalam penelitian ini akan dilakukan analisis terhadap pengungkapan sukarela, maka terdapat beberapa variabel yang menjadi turunan dari pengungkapan sukarela yang masing-masing variabel terdapat indikator-indikator. Untuk lebih jelasnya akan dibahas dalam tabel 1 dibawah ini:

Tabel 1. Ringkasan Pengungkapan Sukarela

\begin{tabular}{|l|ll|}
\hline No & Variabel \\
\hline 1 & Latar belakang informasi (background information) & \\
\hline 2 & Statistika non keuangan penting (key non-financial statistics) & \\
\hline 3 & Informasi yang diproyeksikan (projected information) \\
\hline 4 & $\begin{array}{l}\text { Penjelasan atas perubahan harus diberikan (Management and } \\
\text { discussion analysis) }\end{array}$ \\
\hline
\end{tabular}

Sumber: Wardani (2012), Haryanto dan Yunita

\subsection{ANALISIS DATA}

Teknik yang digunakan dalam penelitian ini menggunakan teknik content analysis terhadap laporan tahunan perusahaan. Content analysis merupakan metode penelitian observasi yang digunakan untuk mengevaluasi secara sistematis isi dari suatu informasi (Sekaran, 2010).

Langkah-langkah dalam menganalisis data akan disajikan dengan tahapan-tahapan sebagai berikut :

a. Memberikan bobot nilai dengan angka 1 jika diungkapkan dan 0 jika tidak diungkapkan dari item-item yang menjadi indikator pengungkapan dalam tabel 1 baik berupa gambar maupun kata-kata. Lalu hasilnya dihitung dengan menggunakan index of disclosure methodology, yaitu indeks Wallace.

$$
\text { Disclosure Index }=\frac{n}{k} \times 100 \%
$$


Dimana :

$\mathrm{n}=$ Pengungkapan yang dilaksanakan

$\mathrm{k}=$ Jumlah item yang dianjurkan untuk diungkapkan

b. Menghitung jumlah panjangnya kata yang berkaitan dengan item pengungkapan dalam tabel 1. Perhitungan ini dilakukan untuk menangkap maksud dari hal-hal yang diungkapkan.

c. Memberikan peringkat hasil dari perhitungan pembobotan nilai pada langkah pertama dan perhitungan jumlah kata yang diungkapkan pada langkah kedua.

d. Melakukan eksplorasi terhadap hasil penelitian sesuai dengan hasil yang dipaparkan pada penelitian terdahulu, lalu memberikan kesimpulan secara umum dari hasil penelitian.

\section{PEMBAHASAN}

Pembahasan dalam penelitian ini ditujukan untuk menjelaskan hasil penelitian sesuai dengan tujuan penelitian. Hasil pembahasan lebih lanjut akan dijelaskan secara rinci di bawah ini dengan menguraikan perubahanperubahan yang terjadi pada item-item pengungkapan dari masing-masing variabel penelitian.

Grafik 1. Gabungan Hasil Perhitungan Nilai IP dan PP Dimensi Latar Belakang Informasi Tahun 2011-2013

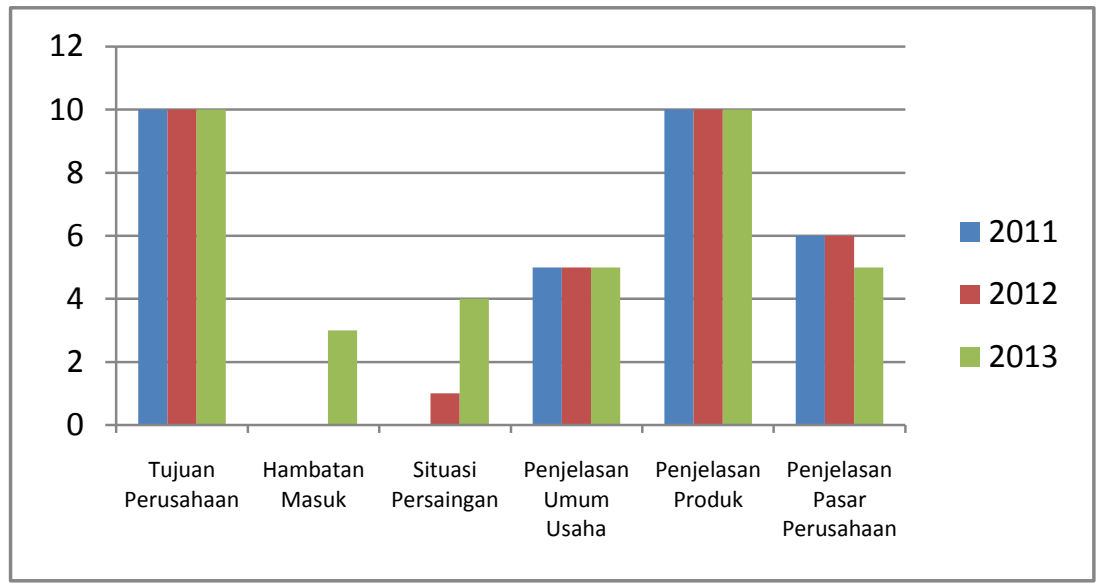

Sumber: Data diolah, 2014

Secara keseluruhan semua BUS mampu untuk mengungkapkan beberapa item yang menjadi variabel ini. Hal ini terjadi karena hingga akhir periode penelitian semua item tersebut berhasil diungkapkan oleh BUS sehingga tidak adanya item yang tidak diungkapkan. Dan hampir seluruh BUS mengalami peningkatan di tahun 2013 karena bertambahnya jumlah 
item yang diungkapkan, dengan BMI berhasil mengungkapkan seluruh item yang terdapat dalam variabel ini, kemudian disusul oleh BSM dan BRIS. Hal ini dirasa wajar karena BMI merupakan bank syariah pertama dan sudah seharusnya bisa memberikan contoh kepada BUS lainnya. Namun, sangat disayangkan untuk BMSI yang hingga akhir tahun 2013 hanya bisa mengungkapkan dua item kalah dengan BSB yang bisa mencapai empat item, padahal BMSI lebih dahulu berdiri tahun 2004 dibandingkan dengan BSB yang baru muncul tahun 2008.

Grafik 2. Gabungan Hasil Perhitungan Nilai IP dan PP Dimensi Statistika Non Keuangan Tahun 2011-2013

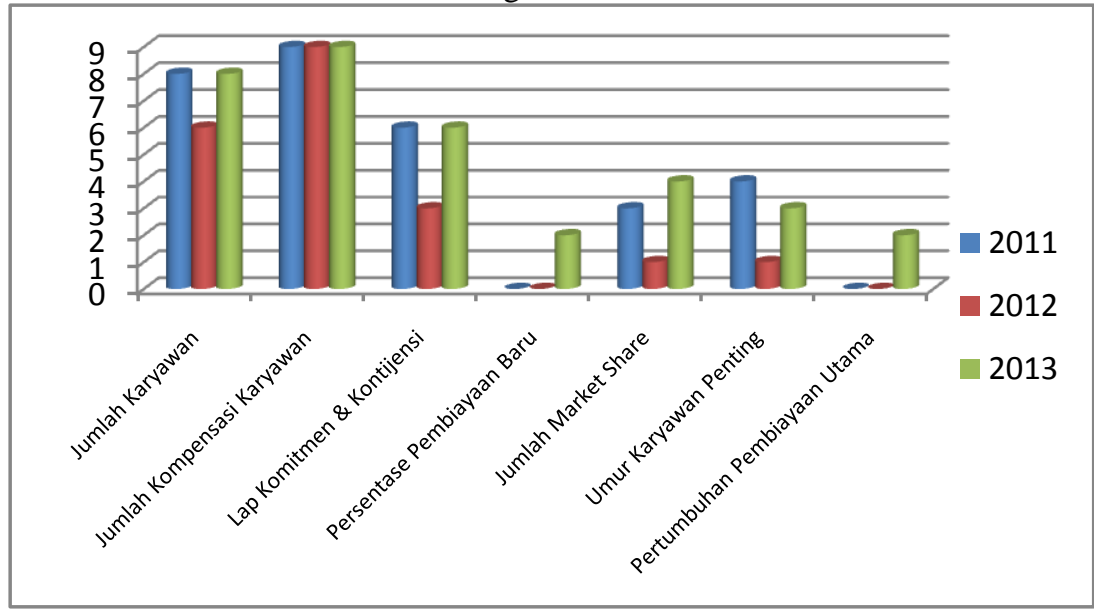

Sumber: Data diolah, 2014

Secara keseluruhan hampir seluruh BUS mampu untuk mengungkapkan beberapa item yang menjadi variabel ini karena tercatat hanya dua item yang tidak diungkapkan oleh semua BUS dari tujuh item yang tersedia. Dan selama tiga periode penelitian, hanya BMI dan BNIS yang mengalami peningkatan terhadap jumlah item yang diungkapkan karena keduanya berhasil mengungkapkan enam item hingga akhir tahun 2013. BSM yang seharusnya bisa mengungkapkan sebanyak enam item mengikuti BMI justru hanya mengungkapkan empat item yang jumlahnya lebih sedikit dari BNIS, padahal BSM merupakan bank syariah kedua setelah BMI.

Dari seluruh item yang terdapat dalam variabel kedua ini, selama tiga tahun periode penelitian BUS yang telah lama berdiri tidak mampu memberikan pengungkapan. BMSI yang seharusnya mampu memberikan pengungkapan karena telah berdiri di tahun 2004, justru merupakan salah satu BUS yang lebih banyak tidak memberikan pengungkapan, terlebih lagi pada item 'jumlah market share' dan 'umur karyawan penting'. Begitu pula yang terjadi pada BMI dan BSM yang keduanya merupakan bank syariah pertama dan kedua yang telah berdiri di tahun 1900 an dibandingkan dengan BSB, BNIS, dan BCAS yang baru berdiri tahun 2008 ke atas. 
Grafik 3. Gabungan Hasil Perhitungan Nilai IP dan PP Dimensi Informasi yang Diproyeksikan 2011-2013

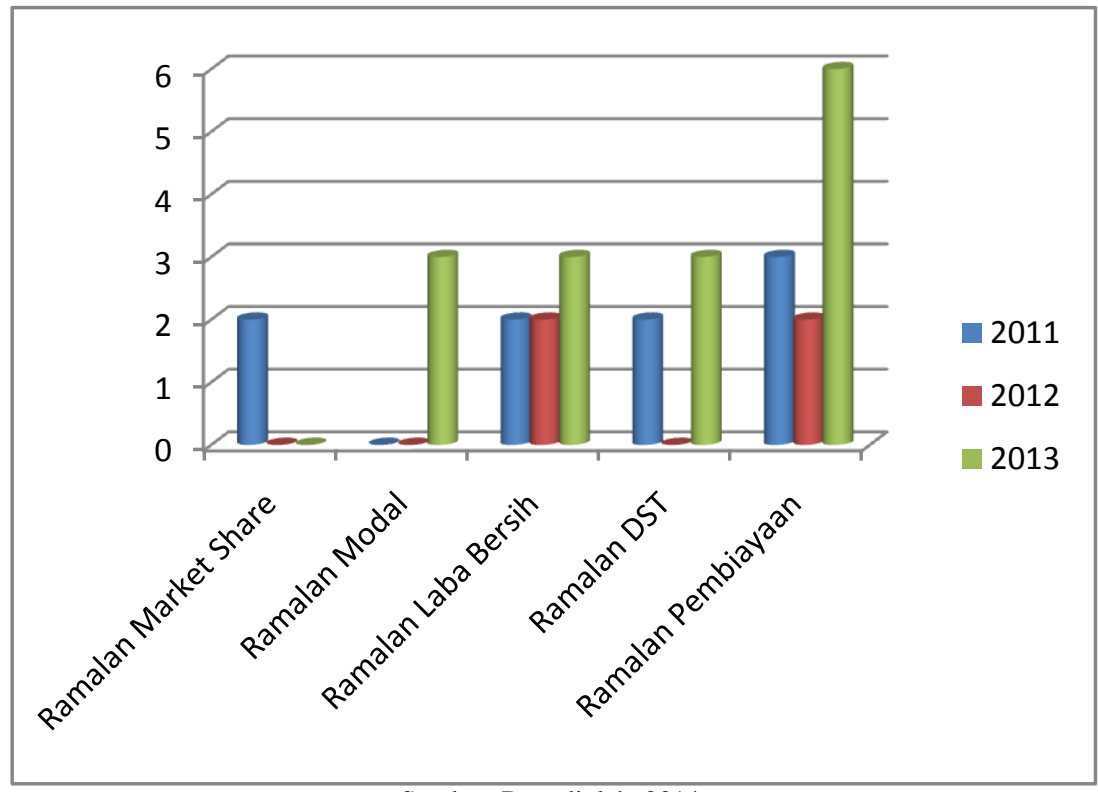

Sumber: Data diolah, 2014

Grafik 4. Gabungan Hasil Perhitungan Nilai IP dan PP Dimensi Penjelasan atas Perubahan Harus Diberikan Tahun 2011-2013

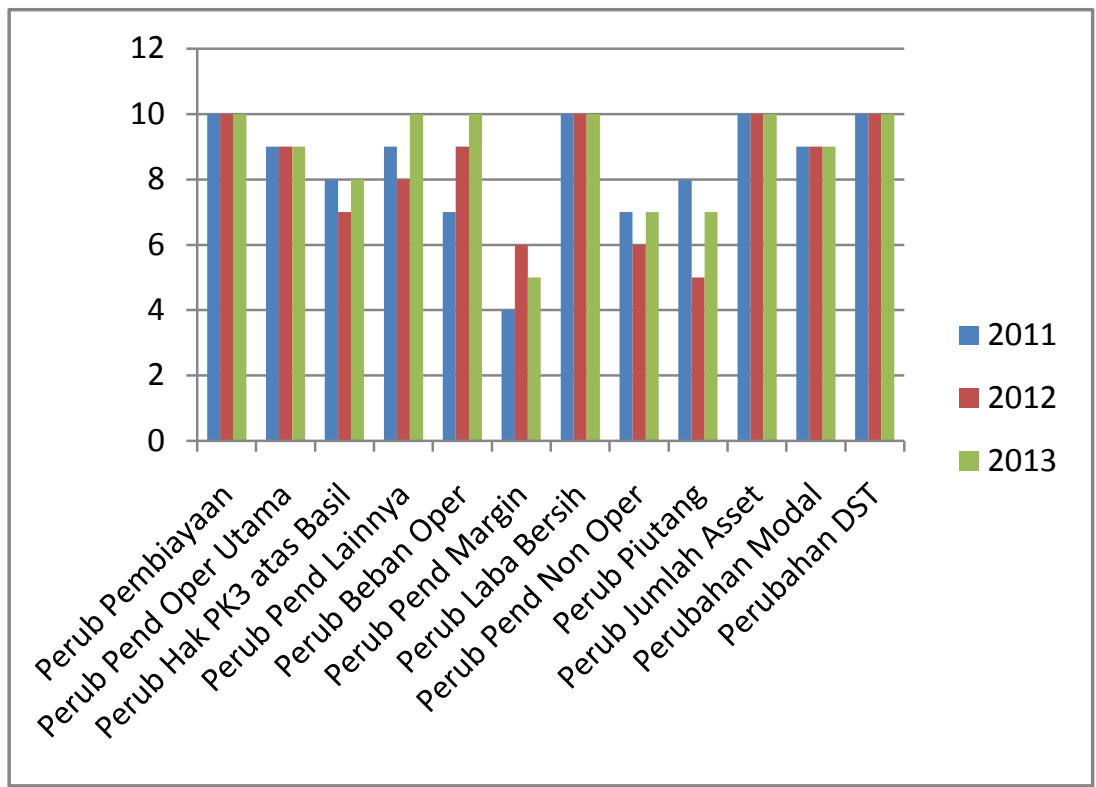

Sumber: Data diolah, 2014 
Selama periode penelitian tahun 2011 hingga 2013 BVS berusaha untuk mengungkapkan beberapa hal yang menjadi item pada variabel 'informasi yang diproyeksikan. Meskipun pada tahun 2012 BVS tidak mengungkapkan keseluruhan item dalam variabel tersebut, namun pada tahun selanjutnya BVS mulai mengungkapkan walaupun hanya empat item yang diungkapkan oleh BVS paling banyak di tahun 2013. Akan tetapi, hal ini dirasa cukup bagus oleh peneliti mengingat BVS merupakan bank syariah yang baru berdiri di tahun 2010 mampu mengungkapkan item yang menjadi variabel 'informasi yang diproyeksikan', dibandingkan dengan BMI yang merupakan bank syariah tertua karena telah berdiri di tahun 1991 tidak bisa mengungkapkan item-item tersebut selama dua tahun periode penelitian dan baru mengungkapkan item tersebut di tahun 2013 itu pula hanya dua item saja. Dari seluruh item yang terdapat dalam variabel ketiga ini hanya BNIS dan BVS yang mampu memberikan pengungkapan selama tiga tahun periode penelitian dibandingkan dengan BMI yang selama tiga tahun tidak bisa mengungkapkan item 'ramalan laba bersih'.

Grafik 5. Peringkat IP Sukarela dalam Laporan Tahunan BUS di Indonesia Tahun 2011-2013

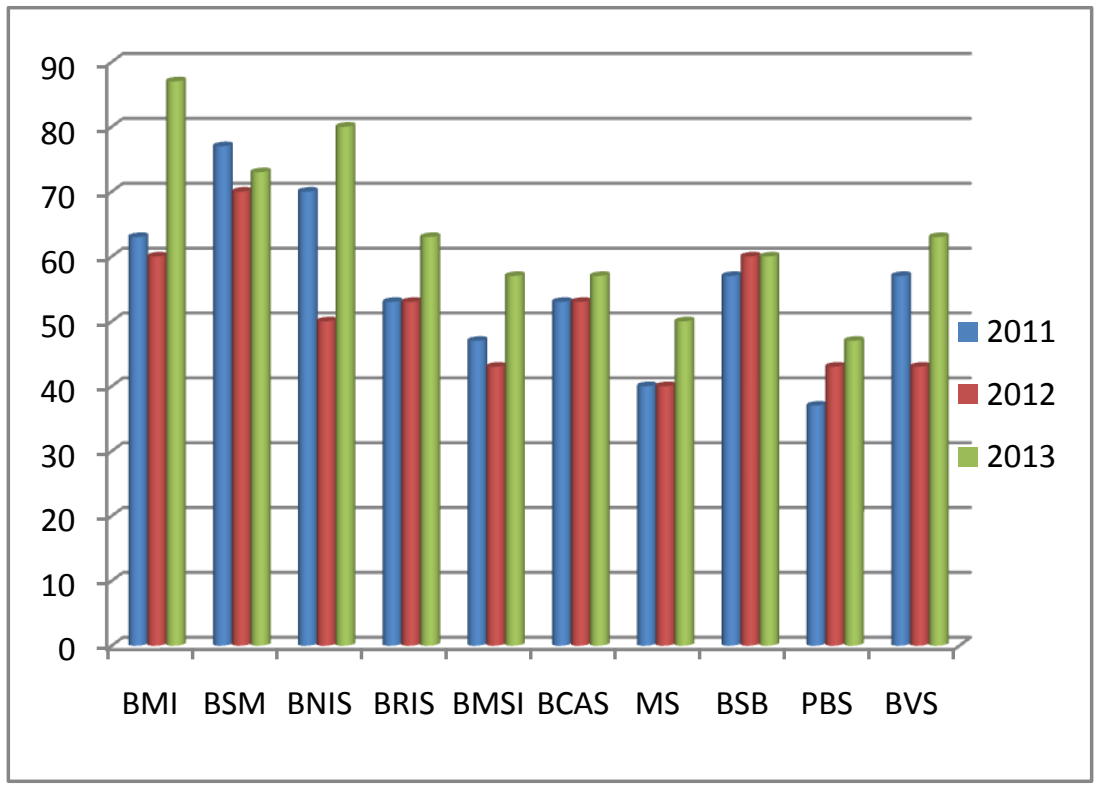

Sumber: Data diolah, 2014

Secara keseluruhan seluruh BUS sudah mampu untuk mengungkapkan beberapa item yang terdapat dalam variabel ini. Meskipun dari masing-masing BUS masih ada yang belum konsisten untuk tetap memberikan pengungkapan pada salah satu item hingga akhir tahun penelitian, akan tetapi selama tiga tahun penelitian dilakukan terjadi peningkatan dari jumlah item yang diungkapkan. Dan pada tahun 2013 BMI, BSM, dan BCAS berhasil mengungkapkan keseluruhan item sebanya dua 
belas item disusul setelahnya oleh BNIS dan BVS yang berhasil mengungkapkan sebelas item. Uniknya, BCAS dan BVS yang keduanya sama-sama baru berdiri tahun 2010 mampu mengungkapkan lebih dari sepuluh item dalam variabel ini mengalahkan BMSI yang hanya mengungkapkan sepuluh item dan BRIS yang mengungkapkan sembilan item, padahal kedua BUS tersebut merupakan bank syariah yang telah lama berdiri.

Pada tahun 2011 terdapat dua BUS yang mendapat peringkat keempat dan kelima, yaitu BSB dan BVS yang keduanya mendapat peringkat keempat dan BRIS dan BMSI yang mendapat peringkat kelima. Kemudian tahun 2012 kesamaan peringkat bertambah menjadi tujuh BUS, yaitu BMI dan BSB yang mendapat peringkat kedua, BRIS dan BCAS yang mendapat peringkat ketiga, dan BMSI, PBS, dan BVS yang mendapat peringkat kelima. Dan pada akhir penelitian 2013 kembali terulang seperti tahun 2011 dimana empat BUS mendapat peringkat yang sama, yaitu BRIS dan BVS yang keduanya mendapat peringkat keempat secara bersamaan dan BMSI dan BCAS yang mendapat peringkat keenam.

Selama tiga periode penelitian, secara keseluruhan terdapat kesamaan peringkat yang diraih oleh BUS. Hal ini dirasa wajar karena adanya BUS yang mendapat skor yang sama tiap tahunnya sehingga membuat peneliti agak sulit untuk menentukan peringkat pertama sampai kesepuluh secara berurutan tiap tahunnya karena ada beberapa item yang hampir seluruh BUS kompak untuk tidak memberikan pengungkapan pada item tersebut sehingga itulah yang menyebabkan adanya kesamaan skor dan peringkat. Akan tetapi untuk tiga peringkat atas secara umum dikuasai oleh bank syariah yang telah lama berdiri, yaitu BMI, BSM dan BNIS.

Grafik 6. Peringkat PP Sukarela dalam Laporan Tahunan BUS di Indonesia Tahun 2011-2013

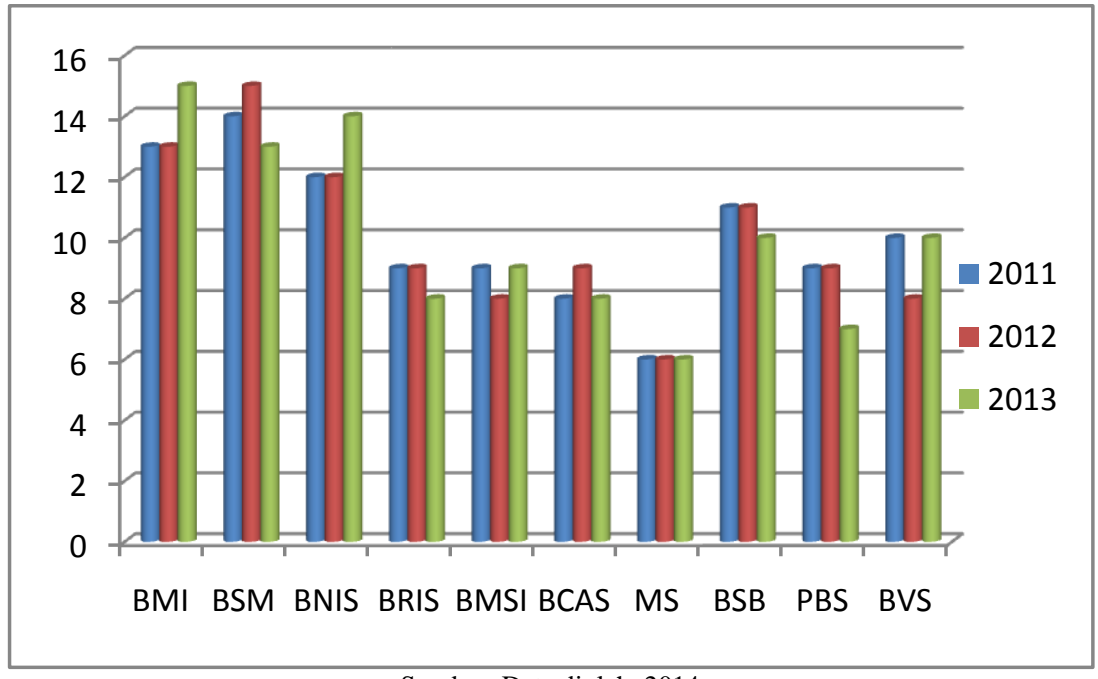

Sumber: Data diolah, 2014 
Selama dua tahun penelitian 2011 dan 2012 peringkat pertama dan kedua diraih oleh BSM dan BMI. Padahal BMI seharusnya mendapat peringkat pertama karena telah berdiri lebih dahulu dibanding BSM. Kemudian di akhir penelitian 2013 terjadi perubahan peringkat dimana BMI bisa mendapat peringkat pertama, akan tetapi BSM mengalami penurunan peringkat menjadi ketiga dari sebelumnya berada di pertama. Selama tiga tahun penelitian tidak terjadinya perubahan peringkat pada tiga BUS, yaitu BSB yang mendapat peringkat keempat, BRIS dengan peringkat ketujuh, dan MS yang selalu berada di peringkat kesepuluh.

Selama tiga tahun penelitian, terjadi peningkatan pada item pengungkapan yang diberikan oleh masing-masing BUS. Hal ini terjadi, karena sudah adanya tuntutan dari lembaga yang mengatur bahwasanya seluruh perusahaan harus mampu memberikan pengungkapan seluas-luasnya agar bisa dinikmati oleh khalayak banyak. Meskipun memang pada hakikatnya titik berat pengungkapan adalah investor yang disebabkan karena kurangnya pengetahuan akan keputusan yang akan diambil oleh pihak lain dan diluar investor, karena bagi investor keputusan yang diingingkan adalah membeli, menjual, dan mempertahankan saham sedangkan keputusan kreditur berkaitan dengan perpanjangan kredit dan pemberian kredit perusahaan. Dan inilah yang membuat tujuan pelaporan kepada pegawai konsumen dan masyarakat umum sulit dirumuskan, karena dianggap bahwa informasi yang berguna bagi investor dan kreditur juga berguna bagi pihak lain.

\section{SIMPULAN}

Berdasarkan analisis di atas, dapat disimpulkan bahwa pengungkapan sukarela yang dilakukan oleh seluruh BUS yang menjadi sampel dalam penelitian ini secara keseluruhan sudah memadai. Namun perjalanan selama penelitian tiga tahun terjadi peningkatan dalam pemberian pengungkapan baik dari segi jumlah kata yang diungkapkan maupun jumlah BUS yang mengungkapkan. Hal ini terjadi karena seluruh BUS mampu memberikan pengungkapan sukarela melalui variabel-variabel yang dijadikan dalam penelitian ini. Selain itu pula, penelitian ini juga menyimpulkan bahwa ratarata BUS yang luas pengungkapan sukarelanya merupakan bank-bank syariah yang telah berdiri lama pada peringkat pertama dan kedua. Meskipun pada peringkat setelahnya ditempati oleh BUS yang baru berdiri di tahun 2010 . Dengan demikian, kesepuluh BUS tersebut seiring berjalannya waktu mampu mengungkapkan item-item yang terdapat dalam variabel pengungkapan sukarela pada laporan tahunan dan pengungkapan yang diberikan oleh kesepuluh BUS tersebut sudah memenuhi pengungkapan sukarela yang semestinya dilaporkan.

\section{DAFTAR PUSTAKA}


Undang-Undang Republik Indonesia No 21 Tahun 2008 Tentang Perbankan Syariah. (2008, Juli 16). Jakarta.

Accounting and Auditing Organisation for Islamic Financial Institutions. (2001). Accounting, Auditing and Governance Standards for Islamic Financial Institutions. Bahrain: AAOIFI.

Almilia, L. S. (2008). Faktor-Faktor yang Mempengaruhi Pengungkapan Sukarela "Internet Financial and Sustainability Reporting". Jurnal Akuntansi dan Auditing Indonesia Vol. 12 No. 2 Desember 2008.

Bank Indonesia. (2014). Statistik Perbankan Syariah (Islamic Banking Statistics) Desember 2014. Jakarta: Direktorat Perbankan Syariah Bank Indonesia.

Daniel, N. U. (2013). Pengaruh Ukuran Perusahaan, Leverage dan Likuiditas Terhadap Luas Pengungkapan Laporan Keuangan (Studi Empriris pada Perusahaan Manufaktur yang Terdaftar di Bursa Efek Indonesia). 8 .

Hadi, N. (2001). Analisis Faktor-Faktor yang Mempengaruhi Luas Pengungkapan Sukarela dalam Laporan Tahunan Perusahaan Go Publik di Bursa Efek. Thesis.

Hardiningsih, P. (2008). Analisis Faktor-Faktor yang Mempengaruhi Voluntary Disclosure Laporan Tahunan Perusahaan. Jurnal Bisnis dan Ekonomi (JBE), 70.

Ikatan Akuntan Indonesia (IAI). (2009). Kerangka Dasar Penyusunan dan Penyajian Laporan Keuangan Syariah. Jakarta: Dewan Standar Akuntansi Keuangan Ikatan Akuntan Indonesia.

Kieso, D. E., Weygandt, J., \& Wardfield, T. (2002). Pengungkapan Penuh Dalam Laporan Keuangan. Dalam Akuntansi Intermediate. Jakarta: Erlangga.

Lestari, S. R. (2010). Analisis Pengungkapan Informasi Intellectual Capital Dalam Laporan Tahunan Perusahaan Perbankan Syariah. Skripsi, Sarjana Program Studi Akuntansi Syariah Sekolah Tinngi Ekonomi Islam SEBI, Depok 42-44.

Sugiyono. (2008). Dalam Metode Penelitian Kuantitatif, Kualitatif dan R\&D. Bandung: Alfabeta Bandung.

Suryana, A. (2007). Tahap-tahap Penelitian Kualitatif. Bandung: Fakultas Ilmu Pendidikan UPI.

Testiana, D. (2012). Analisis Pengaruh Karakteristik Perusahaan Terhadap Kelengkapan Pengungkapan Sukarela Pada Perusahaan Manufaktur yang Terdaftar di Bursa Efek Indonesia. 2.

Tristanti, L. L. (2012). Analisis Pengaruh Karakteristik Perusahaan Terhadap Kelengkapan Pengungkapan Sukarela (Studi Empiris pada Perusahaan 
Manufaktur yang Terdaftar di Bursa Efek Indonesia Tahun 20062010). Skripsi.

Wardani, R. P. (2012). Faktor-Faktor yang Mempengaruhi Luas Pengungkapan Sukarela. Jurnal Akuntansi dan Keuangan Vol. 14.

Zahrah, P. M. (2012). Hukum Taklifi. Dalam USHUL FIQIH (hal. 30). Jakarta: PT. Pustaka Firdaus. 
